\title{
Prospek Implementasi Reforma Agraria di Indonesia Setelah Terbitnya Peraturan Presiden No. 86 Tahun 2018
}

\author{
Arsan Nurrokhman \\ Pusat Penelitian dan Pengembangan, Kementerian Agraria dan Tata \\ Ruang/Badan Pertanahan Nasional
}

Intisari: Reforma agraria adalah misi utama Undang-Undang Nomor 5 Tahun 1960 tentang Peraturan Dasar Pokok-Pokok Agraria (UUPA). Undang-undang yang banyak dipuji sebagai karya agung bangsa Indonesia yang revolusioner, responsif dan memadukan unsur-unsur yang baik antara paham individualisme dan komunalisme. Tetapi tidak tercapainya misi utama UUPA tersebut susah dipungkiri dan mayoritas pembelaan atas kegagalannya cenderung normatif dan ideologis. Tulisan ini bertujuan membawa studi atas UUPA ke arah lebih empirik dengan menggunakan teori-teori implementasi kebijakan publik, seperti yang dikenalkan Grindle (1980) tentang variabel konten dan konteks kebijakan. Juga teori para peneliti implementasi yang kritis yang menggunakan perspektif bottom-up dan menyoroti tindakan birokrat pelaksana. Penelitian menggunakan metode kualitatif melalui studi literatur dan fokus pada kebijakan eksekutif, tindakan birokrat dan serta konteks yang melingkupinya. Penelitian menemukan bahwa kebijakan eksekutif dengan terbitnya Peraturan Presiden Republik Indonesia Nomor 86 Tahun 2018 justeru tidak selaras dengan beberapa ketentuan UUPA. Peraturan presiden tersebut memiliki paradoks, ingin mengakomodir banyak variabel tetapi mengalami kebingungan atas tujuan utama reforma agraria. Sebagai kebijakan yang relatif top down, implementasi UUPA sebenarnya memerlukan adanya aktor yang dominan. Namun tindakan birokrat pelaksana (street level bureaucrat) telah lama mereduksi tujuan undangundang menjadi sekedar tindakan legalisasi terhadap pembukuan transaksi atas tanah yang berjalan sesuai mekanisme pasar. Kini, semakin banyaknya penduduk Indonesia yang tinggal di wilayah perkotaan membuat isu tentang tanah lebih kompleks, terkait dengan alih fungsi lahan dan berbagai tantangan pembangunan berkelanjutan. Berbagai kondisi tersebut membuat prospek implementasi reforma agraria di Indonesia setelah terbitnya Peraturan Presiden 86/2018 masih belum menggembirakan. Masih diperlukan kebijakan yang mengakomodir misi utama UUPA dan perkembangan perkotaan.

Kata Kunci: reforma agraria, implementasi kebijakan publik, administrasi pertanahan

\footnotetext{
${ }^{1}$ Versi Bahasa Inggris dari tulisan ini terbit di Jurnal BHUMI, Vol 5, No 3 (2019) dengan judul Quo Vadis Indonesian Agrarian Reform: Implementation of UUPA in the President Regulation No. 86 of 2018.
} 


\section{A. Pendahuluan}

Reforma agraria adalah misi utama Undang-Undang Nomor 5 Tahun 1960 tentang Peraturan Dasar Pokok-Pokok Agraria (UUPA). Guna menjalankan misi tersebut, UUPA mengamanatkan adanya upaya perombakan hukum agraria, pelaksanaan landreform, penataan penggunaan tanah, likuidasi hakhak asing dalam bidang agraria dan penghapusan sisa-sisa feodalisme dalam bidang agraria.

UUPA sendiri banyak dipuji sebagai karya agung bangsa Indonesia yang revolusioner, responsif dan memadukan unsur-unsur yang baik antara paham individualisme dan komunalisme. Sodiki (2013) menjelaskan bahwa warisan nilai-nilai dalam UUPA yang masih relevan adalah anti penjajahan, anti eksploitasi kekayaan dan populis. UUPA kuat hasratnya menampilkan identas hukum asli bangsa Indonesia, egaliter dan membuat kedudukan negara kuat sehingga negara dapat menjamin terpenuhinya kepentingan umum. UUPA adalah satu-satunya undang-undang yang berhasil menjelmakan tiap sila dari Pancasila dalam beberapa pokoknya Soetiknyo (1990). UUPA juga berkarakter reponsif meskipun lahir pada saat konfigurasi politik berjalan sangat otoriter (Mahfud MD dalam Sodiki et al., 2013).

Tetapi tidak tercapainya misi undang-undang tersebut, kesejahteraan petani dan prinsip tanah untuk penggarap (land to the tiller), adalah fakta yang susah diingkari. Jika rasio gini penguasaan lahan dijadikan ukuran, maka angka ketimpangan penguasan lahan tetap tinggi setelah UUPA berusia lebih dari setengah abad. Rasio gini penguasaan lahan di Indonesia pada tahun 1973 adalah o,70; tahun 1983 adalah o,64; tahun 1993 adalah o,67; tahun 2003 adalah 0,72 (Bachriadi dan Wiradi 2011) dan pada tahun 2013 mencapai o,64 (INDEF, 2017).

Pembelaan atas tidak tercapainya tujuan UUPA telah dibuat oleh banyak kalangan. Menurut Soetiknjo (1990), UUPA belum dapat memecahkan masalah tanah karena undang-undang tersebut adalah hukum dalam keadaan tidak bergerak (het recht in rust) yang hanya memuat pokok-pokoknya saja. Hal yang menggerakkan adalah peraturan-peraturan pelaksanaannya. Sodiki (2013) menyadari adanya masalah efektifitas UUPA. Namun ia justeru menyebut kemungkinan kurang berhasilnya UUPA karena kurang menghiraukan ketentuan lokal yang lebih bisa menyelesaikan masalah setempat daripada UUPA yang ingin menghapuskan lembaga adat. Sedangkan menurut Mahfud MD (2018), sekarang UUPA dan beberapa undang-undang ikutannya tidak pernah diimplementasikan karena kebijakan pembangunan yang situasional. Ia berpendapat bahwa hukum-hukum agraria harus ditata lagi.

Peraturan-peraturan pelaksanaan UUPA sebetulnya sudah banyak terbit. Baik berupa peraturan pemerintah, peraturan presiden dan peraturan menteri. Namun banyaknya tujuan UUPA yang belum terwujud, khususnya yang terkait dengan reforma agraria, membuat studi terhadap UUPA dengan menggunakan 
perspektif implementasi kebijakan publik penting untuk dilakukan. Apakah terdapat masalah implementasi kebijakan reforma agraria dalam konten kebijakan dan konteks lingkungannya? Apa saja yang dilakukan oleh para birokrat yang diberi amanat untuk menjalankan undang-undang tersebut?

Metode yang digunakan dalam penelitian ini adalah metode kualitatif. Penelitian dilakukan melalui studi literatur terhadap kebijakan yang dibuat sebagai turunan UUPA dan observasi di Kantor Pertanahan. Data yang digunakan adalah data sekunder berupa peraturan-peraturan dan data primer berupa hasil observasi tindakan birokrat dalam menjalankan peraturan.

\section{B. Kerangka Teoritik Implementasi Kebijakan Publik}

Implementasi adalah apa yang terjadi setelah undang-undang ditetapkan yang memberikan otoritas program, kebijakan, keuntungan (benefit) atau suatu jenis keluaran yang nyata (tangible output). Istilah implementasi mencakup tindakan-tindakan (dan tanpa tindakan-tindakan) oleh berbagai aktor, khususnya birokrat yang dimaksudkan untuk membuat program berjalan (Ripley dan Franklin dalam Winarno, 2014). Menurut Matland (dalam Hamdi, 2014), literatur mengenai implementasi kebijakan secara umum terbagi dalam dua kelompok, yakni kelompok dengan pendekatan dari atas (top-down) dan kelompok dengan pendekatan dari bawah (bottom-up). Kelompok dengan pendekatan top down melihat perancang kebijakan sebagai aktor sentral dalam implementasi kebijakan. Selain itu, kelompok ini juga memusatkan perhatiannya pada faktor-faktor yang dapat dimanipulasi pada tingkat sentral atau pada variabel yang bersifat makro. Sementara, kelompok bottom up menekankan pada dua hal, yakni kelompok-kelompok sasaran dan para penyedia layanan.

Pakar yang dikenal pertama kali membuat model implementasi dengan pendekatan top-down adalah Van Meter dan Van Horn (1975). Meskipun ia bukan yang pertama kali melakukan studi implementasi kebijakan. Mereka menyatakan bahwa implementasi kebijakan menyangkut (encompasses) semua tindakan oleh perorangan atau kelompok publik dan privat yang diarahkan pada perwujudan tujuan yang telah ditetapkan terlebih dahulu dalam putusan kebijakan. Model mereka terdiri atas enam variabel yang membentuk kaitan antara kebijakan dan performa seperti berikut: 1) Standar dan tujuan kebijakan, 2) Sumberdaya kebijakan, 3) Komunikasi dan aktivitas penguatan antar organisasi, 4) Karakteristik jawatan pelaksana, 5) Kondisi ekonomi, politik dan sosial dan 6) Disposisi pelaksana (Hamdi, 2014).

Selain Van Meter dan Van Horn, pakar yang kemudian merumuskan model implementasi adalah Grindle (1980) yang menyatakan bahwa implementasi adalah proses politik dan proses administratif yang keberhasilannya dipengaruhi oleh dua variabel yang fundamental, yaitu konten atau isi kebijakan (content of policy) dan konteks atau lingkungan implementasi (context of implementation). Namun dari sejumlah pakar yang 
dapat digolongkan sebagai pengikut top-down, model yang dibangun oleh Sabatier dan Mazmanian(1983) adalah yang paling lengkap dalam meramu berbagai variabel hasil karya para pakar sebelumnya hingga menjadi model yang komprehensif. Variabel-variabel tersebut dikelompokkan menjadi tiga jenis, yaitu 1) tractability of the problem; 2) ability of statute to structur implementation; dan 3) non statutory variable (Purwanto \& Sulistyastuti, 2015).

Selain pandangan kalangan top-down, perlu diperhatikan juga kritik kalangan bottom-up. Menurut Sabatier (dalam Purwanto, 2015), pada dasarnya ada empat kritik yang dilontarkan terhadap pendekatan top-down oleh para peneliti implementasi yang kritis seperti Hjern dan Hull (1982), Hanf (1982), Barrett dan Fudge (1981) dan Elmore (1979). Empat kelemahan pendekatan tersebut adalah: 1) menganggap bahwa aktor utama yang paling berpengaruh terhadap dalam implementasi adalah para policy maker, sehingga mereka lupa bahwa keberhasilan atau kegagalan implementasi dapat dipengaruhi oleh aktor-aktor lain yaitu birokrat garda depan, kelompok sasaran, sektor swasta dan lain-lain; 2) pendekatan top-down sulit diterapkan ketika tidak ada aktor yang dominan; 3) pendekatan top-down melupakan kenyataan bahwa birokrat garda depan dan kelompok sasaran memiliki kecenderungan menyelewengkan arah kebijakan bagi kepentingan mereka masing-masing; 4) siklus kebijakan itu sendiri sering tahapan-tahapannya tidak bersifat clear-cut, sehingga membuka ruang bagi birokrat garda depan dan kelompok sasaran untuk mempengaruhi dan melakukan negosiasi pada saat formulasi kebijakan.

Beberapa variabel dari teori implementasi kebijakan tersebut akan digunakan untuk menelaah kebijakan reforma agraria. Kebijakan eksekutif yang akan dikaji adalah Peraturan Presiden Republik Indonesia Nomor 86 Tahun 2018. Tindakan birokrat garda depan adalah para pelaksana kebijakan di Kementerian Agraria dan Tata Ruang/BPN. Konteks kebijakan adalah kondisi di Indonesia yang terkait dengan tanah dan populasi.

\section{Kebijakan eksekutif reforma agraria dalam Peraturan Presiden Republik Indonesia Nomor 86 Tahun 2018}

Variabel kejelasan dan konsistensi tujuan adalah bagian dari kategori kemampuan undang-undang untuk dimplementasikan dalam model implementasi Mazmanian dan Sabatier (1983). Jika diterapkan untuk menelaah peraturan presiden ini maka akan menemukan inkonsistensi dalam isinya. Inkonsistensi tersebut ada dalam beberapa aspek, baik menyangkut kegiatan yang akan dilaksanakan, subyek dan obyek reforma agraria.

Pasal 5 Peraturan Presiden No 86/2018 menyebutkan bahwa pelaksanaan Reforma Agraria dilaksanakan melalui tahapan penataan aset dan penataan akses. Urutan pelaksanaan bahwa penataan aset menjadi dasar dilakukannya penataan akses seperti menjadi rangkaian kegiatan yang berkelanjutan. 
Seolah-olah setelah seorang petani mendapatkan tanah (melalui penataan aset) akan dilanjutkan dengan pemberdayaan untuk mendapat akses terhadap modal, peningkatan produksi dan pasar. Rangkaian yang sesuai dengan role reform dan development seperti disampaikan oleh Dorner (1972) yang menjelaskan bahwa "reform has dual purpose of serving as both a redistributive instrument and vehicle for achieving increased productivity. To achieve the latter, land reform must be accomponied by changes in the prereform structure of supporting services - agricultural credit, marketing, research and extension, input supply, and processing and storage."

Tetapi penataan aset tersebut ternyata direduksi dalam pasal 6 sebagai kegiatan yang terpisah dalam bentuk redistribusi atau legalisasi aset saja. Kegiatan legalisasi aset saja bisa diklaim sebagai kegiatan penataan aset berdasarkan peraturan ini. Padahal inti dari kegiatan reforma agraria adalah redistribusi tanah karena tujuan pertama reforma agraria seperti disebut dalam pasal 2 adalah mengurangi ketimpangan penguasaan dan pemilikan tanah dalam rangka menciptakan keadilan.

Pasal 6 Peraturan Presiden No 86/2018 tersebut seperti menegaskan bahwa reforma agraria bisa berjalan tanpa adanya redistribusi tanah. Peraturan reforma agraria ini tidak hendak memberikan tanah kepada petani dan menambah aksesnya terhadap modal, tetapi cukup mengganti kegiatan redistribusi tanah dengan melakukan legalisasi aset. Padahal faktanya banyak petani penggarap yang tidak punya tanah untuk dilegalisasi dan ada sekelompok orang yang mengakumulasi kepemilikan atau penguasaan tanah.

Realita belum terwujudnya pemerataan struktur penguasaan, pemilikan, penggunaan dan pemanfaatan tanah sebetulnya diakui karena disebut di dalam konsideran peraturan presiden tersebut. Konsideran pertama peraturan ini menyebutkan "bahwa tanah dalam wilayah Negara Kesatuan Republik Indonesia sebagai karunia Tuhan Yang Maha Esa bagi seluruh Bangsa Indonesia pada tingkatan tertinggi dikuasai oleh negara dipergunakan untuk sebesar-besar kemakmuran rakyat". Point ini ingin menunjukkan hak menguasai negara seperti yang ada juga dalam Pasal 2 UUPA.

Tetapi faktanya, 11 (sebelas) obyek reforma agraria yang disebutkan dalam peraturan tersebut (pasal 7) hampir semuanya adalah tanah bekas atau sisa. Bahkan tanah bekas pertambangan yang mayoritas tidak produktif dan tanah timbul yang tidak signifikan pun turut disebut. Hak menguasai negara seperti tercantum dalam Pasal 2 ayat (2) UUPA teryata belum terwujud. Negara ternyata belum bisa memberi persediaan tanah yang jelas untuk dijadikan obyek reforma agraria.

Subyek reforma agraria yang disebut dalam pasal 12 ayat (3) yang terdiri dari 20 jenis profesi juga menunjukkan inkonsistensi tujuan dari peraturan ini. Penyebutan pekerjaan di luar sektor pertanian, bahkan juga pegawai pemerintahan, tentara dan polisi, tidak selaras dengan prinsip UUPA bahwa prinsip tanah untuk penggarap (land to the tiller). Ketentuan tentang subyek 
tersebut tidak selaras dengan pasal 10 ayat (1) UUPA "Setiap orang dan badan hukum yang mempunyai sesuatu hak atas tanah pertanian pada azasnya diwajibkan mengerjakan atau mengusahakannya sendiri secara aktif, dengan mencegah cara-cara pemerasan."

Berbagai fakta tersebut menunjukkan bahwa Peraturan Presiden No 86/2018 tersebut memiliki banyak paradoks. Peraturan tersebut memiliki ketidaksesuaian dengan asas dalam peraturan di atasnya dan prinsip-prinsip reforma agraria secara umum. Peraturan tersebut ingin mengakomodir penyelesaian banyaknya masalah pertanahan di Indonesia, baik di perdesaan maupun perkotaan, tetapi akhirnya malah mengalami kebingungan atas tujuan utama reforma agraria. Inkonsistensi yang terjadi dalam isinya akan membuat peraturan ini sulit diimplementasikan untuk mencapai tujuannya. Atau jika kategori Richard Matland (dalam Lester \& Goggin, 1998) hanya akan ada implementasi simbolis, ditandai dengan tingginya tingkat konflik dan ambiguitas. Kecuali jika reforma agraria hanya dimaknai legalisasi aset untuk meneguhkan ketimpangan dan status quo.

\section{Tindakan birokrat pelaksana (street level bureaucrat)}

Sebagai kebijakan yang relatif top down, implementasi kebijakan reforma agraria sebagai misi UUPA memerlukan adanya aktor yang dominan. Namun tindakan birokrat pelaksana (street level bureaucrat) telah mereduksi tujuan undang-undang menjadi sekedar tindakan legalisasi terhadap pembukuan transaksi atas tanah yang berjalan sesuai mekanisme pasar.

Pada praktiknya, tindakan yang dilakukan oleh pejabat Kantor Pertanahan (Kementerian Agraria dan Tata Ruang/BPN) adalah mendaftar atau membukukan saja transaksi yang telah dilakukan oleh masyarakat yang melakukan permohonan hak. Observasi yang dilakukan oleh peneliti di beberapa Kantor Pertanahan menunjukkan bahwa kegiatan yang dilakukan oleh para birokrat adalah nyaris hanya sekedar mendaftarkan saja bukti-bukti transaksi jual beli atau hibah dan bukti penguasaan fisik. Seleksi atas kemungkinan akumulasi kepemilikan atau penguasaan tanah praktis tidak dilakukan. Pemohon yang berasal dari luar propinsi dan bukan pegawai negeri ternyata tetap diberikan hak atas tanah pertanian.

Jika pun dilakukan seleksi hanya berdasar keterangan yang sepihak dari masyarakat tanpa ada peninjauan lebih lanjut. Kebenaran materiil atas isi pernyataan juga tidak dilakukan karena alasan bukan kewenangan BPN. Dalam kegiatan Pendaftaran Tanah Sistematis Lengkap, para pelaksana di Kantor Pertanahan tersebut mendasarkan pada Petunjuk Teknis yang diterbitkan oleh Direktorat Jenderal Hubungan Hukum Keagrariaan yang memberikan petunjuk bahwa "Pelaksana PTSL dalam melakukan Penelitian Data Yuridis untuk Pembuktian Hak sebatas pada kebenaran formal, sedangkan kebenaran materil adalah tanggung jawab peserta PTSL" (Petunjuk Teknis Pendaftaran Tanah Sistematis Lengkap Tahun 2019, huruf G angka 1). 
Jika menggunakan analisis implementasi bottom-up seperti yang disampaikan Sabatier (dalam Purwanto, 2015) bahwa dalam siklus kebijakan itu sendiri sering tahapan-tahapannya tidak bersifat clear-cut, sehingga membuka ruang bagi birokrat garda depan dan kelompok sasaran untuk mempengaruhi dan melakukan negosiasi pada saat formulasi kebijakan, maka formulasi kebijakan reforma agraria seperti dalam Peraturan Presiden No. 86/2018 sebetulnya sangat dipengaruhi oleh apa yang dilakukan selama ini oleh birokrat pelaksana di Kementerian Agraria dan Tata Ruang/BPN. Peraturan Presiden tersebut substansinya sangat mirip dengan Peraturan Menteri Agraria dan Tata Ruang terkait Prona atau Pendaftaran Tanah Sistematis Lengkap. Hanya legalisasi aset yang ditambah dengan pencantuman upaya pemberdayaan (penataan akses).

Ketidakjelasan tentang definisi tanah negara dalam praktiknya juga membuat kegiatan redistribusi tanah di Kantor Pertanahan akhirnya hanya sekedar hanya legalisasi aset saja. Tanah yang dijadikan obyek redistribusi tanah sebetulnya mayoritas juga tanah yang telah dikuasai oleh masyarakat. Jika pun ada yang tidak dikuasai oleh masyarakat sebelumnya jumlahnya tidak signifikan. Padahal redistribusi tanah adalah awal dan bagian dari reforma agraria yang sebenarnya. "Agrarian reform to cover all aspects of institutional development Including land reform, tenure production and supporting services structure and related institutions, Such as local government, public administration in rural areas, rural education and rural social welfare institution, and so forth." (United Nations in "Progress in Land Reform, NY Fifth Report, 1970, Vol. III, dalam Wilonoyudho et al, 2017)

\section{E. Konteks kebijakan reforma agraria kekinian}

Semakin banyaknya penduduk Indonesia yang tinggal di wilayah perkotaan membuat isu tentang tanah lebih kompleks. Isu pertanahan akan terkait dengan alih fungsi lahan dan berbagai tantangan pembangunan berkelanjutan. Data Badan Pusat Statistik (2014) menunjukan bahwa persentase penduduk perkotaan di Indonesia terus meningkat dari tahun ke tahun. Pada tahun 2010 persentasenya 49,8\%; tahun 2015 meningkat menjadi $53,3 \%$ dan diproyeksikan tahun 2020 mencapai $56,7 \%$ dan tahun 2025 sudah mencapai $60 \%$.

Konsekuensi yang muncul akibat semakin banyaknya penduduk yang tinggal di wilayah perkotaan tersebut membuat masalah terkait tanah semakin kompleks. Kebutuhan akan tanah bukan lagi hanya untuk lahan pertanian, tetapi juga perumahan. Tantangannya bukan lagi hanya tanah pertanian terakumulasi, tetapi juga karena tanah pertanian telah beralih fungsi. Lebih banyaknya penduduk yang tinggal di wilayah perkotaan ternyata bukan hanya karena bermigrasi ke kota, tetapi karena fenomena urban sprawl (meluasnya fisik kota secara tidak beraturan). Masalah bu kan lagi hanya mengancam petani, tetapi juga keseluruhan populasi dan lingkungan hidup. 
Masalah baru dan kompleks tidak lagi bisa diselesaikan dengan paradigma lama. Pendekatan lebih sistematis dengan alat yang lebih canggih diperlukan untuk menjawab berbagai tantangan tersebut. Sebuah sistem yang bisa menghimpun berbagai informasi penting terkait pertanahan, secara tekstual dan spasial, perlu dibuat untuk mengambil keputusan-keputusan penting. Minimnya informasi yang terintegrasi membuat kebijakan terkait lahan seringkali tidak menjawab masalah aktual.

\section{F. Kesimpulan}

Kebijakan eksekutif dengan terbitnya Peraturan Presiden Republik Indonesia Nomor 86 Tahun 2018 tentang Reforma Agraria justeru tidak selaras dengan beberapa ketentuan UUPA. Peraturan presiden tersebut memiliki paradoks, ingin mengakomodir banyak variabel tetapi mengalami kebingungan atas tujuan utama reforma agraria. Sebagai kebijakan yang relatif top down, implementasi UUPA sebenarnya memerlukan adanya aktor yang dominan. Tetapi tindakan birokrat pelaksana (street level bureaucrat) telah mereduksi tujuan undang-undang menjadi sekedar tindakan legalisasi terhadap penguasaan fisik dan transaksi atas tanah yang berjalan sesuai mekanisme pasar. Konteks kekinian dengan semakin banyaknya penduduk Indonesia yang tinggal di wilayah perkotaan membuat isu tentang tanah lebih kompleks, terkait dengan alih fungsi lahan dan berbagai tantangan pembangunan berkelanjutan. Berbagai paradoks dalam peraturan, reduksi dalam tindakan birokrat dan tantangan lingkungan kebijakan yang semakin kompleks membuat implementasi reforma agraria di Indonesia masih memiliki prospek yang suram. Sebuah sistem yang bisa menghimpun berbagai informasi penting terkait pertanahan, secara tekstual dan spasial, perlu dibuat untuk mengambil keputusan-keputusan penting yang multi tujuan. Masih diperlukan juga kebijakan yang mengakomodir misi utama UUPA dan perkembangan perkotaan.

\section{Daftar Pustaka}

Bachriadi, D, Wiradi, G, Bachrioktora, Y, Safitri, H, \& Agung 2011, Enam dekade ketimpangan: masalah penguasaan tanah di Indonesia, Agrarian Resource Centre (ARC).

Badan Pusat Statistik 2014, Persentase penduduk daerah perkotaan menurut provinsi,2010-2035, dilihat pada 9 November 2019, https://www.bps.go.id/statictable/2014/o2/18/1276/persentasependuduk-daerah-perkotaan-menurut-provinsi-2010-2035.

Dorner, $\mathrm{P}$ 1972, Land reform and economic development, Penguin Books, Harmondsworth, Middlesex.

Guntur, M, \& Yamin, M.N, 2017, September, Determinant factors of village fund policy implementation in Selayar, South Sulawesi Province. In 
2nd International Conference on Education, Science, and Technology (ICEST 2017), Atlantis Press.

Hamdi, M. 2014, Kebijakan publik: proses, analisis dan partisipasi, Penerbit Ghalia Indonesia, Bogor.

INDEF 2017, Turunnya Kesejahteraan, Ketimpangan Lahan, dan Klaim Kepuasan Petani, dilihat pada 9 November 2019, https://money.kompas.com/read/2017/o7/11/o70000526/turunnya.k esejahteraan.ketimpangan.lahan.dan.klaim.kepuasan.petani?page=a 11.

Lee Peluso, N, Afiff, S \& Rachman, NF 2008, Claiming the grounds for reform: agrarian and environmental movements in Indonesia, Journal of Agrarian Change, Vol. 8, No.2-3, p. 377-407.

Lester, JP \& Goggin, ML 1998. Back to the future: the rediscovery of implementation studies. Policy Currents, Vol. 8 No. 3, p. 1-9.

Lucas, A \& Warren C 2013, Land for the people: The state and agrarian conflict in Indonesia, Ohio University Press.

Maladi, Y 2013, Reforma agraria berparadigma Pancasila dalam penataan kembali politik agraria nasional. Mimbar Hukum-Fakultas Hukum Universitas Gadjah Mada, 25(1), 27-41.

Purwanto, EA \& Sulistyastuti, DR 2015. Implementasi kebijakan publik: konsep dan aplikasinya di indonesia. Yogyakarta: Penerbit Gava Media

Sodiki, A, Huda, M, Ana, NR. \& Ali, M M 2013, Politik hukum agraria. Konstitusi Press (Konpress), Jakarta.

Soetiknjo, I 1990. Politik Agraria Nasional. Gadjah Mada University Press.

Widodo, S 2017, A critical review of Indonesia's agrarian reform policy. Journal of Regional and City Planning, Vol. 8 , No. 3, p. 204-218.

Williamson, I, Enemark, S, Wallace, J, \& Rajabifard, A 2010, Land administration for sustainable development, ESRI Press Academic, Redlands, CA.

Wilonoyudho, S, Rijanta, R, Keban, YT, \& Setiawan, B 2017, Urbanization and regional imbalances in Indonesia. Indonesian Journal of Geography, Vol. 49 No. 2, p. 125-132. 